\title{
Glucocorticoid-Stimulated Biosynthesis of Low Density Lipoprotein Receptor in Cultured Fibroblasts
}

\author{
By I. Filipovic and E. Buddecke \\ Institut für Physiologische Chemie der Universität Münster
}

(Received November 8, 1984))

Summary: Preincubation of human skin fibroblasts in the presence of $10^{-6}-10^{-5} \mathrm{~mol} / \mathrm{l}$ glucocorticoids (dexamethasone) causes a concentration and time-dependent increase of receptor-mediated internalisation of [125I]LDL. This increase is due to a glucocorticoid-specific stimulation by $40-50 \%$ of LDL receptor synthesis as demonstrated by an increased incorporation of $\left[{ }^{35} S\right]$ methionine into immune precipitated receptor protein. In contrast the rate of synthesis of total cell protein and of lysosomal cathepsin D is not significantly influenced by dexamethasone.

The increased LDL receptor synthesis is accompanied by an enhanced synthesis of cholesterol from $\left[2-{ }^{3} \mathrm{H}\right]$ mevalonolactone and $\left[1-{ }^{14} \mathrm{C}\right]$ acetate. The glucocorticoid-induced enhancement of LDL receptor and cholesterol synthesis is abolished by preincubation of the cells with dexamethasone in combination with 25-hydroxycholesterol.

\section{Glucocorticoid-stimulierte Biosynthese des LDL-Rezeptors in kultivierten Hautfibroblasten}

Zusammenfassung: Vorinkubation menschlicher Hautfibroblasten in Gegenwart von $10^{-6}-10^{-5} \mathrm{~mol} / \mathrm{l} \mathrm{Gluco}$ corticoiden (Dexamethason) führt zu einer konzentrations- und zeitabhängigen Zunahme der Rezeptorvermittelten Aufnahme von [ $\left.{ }^{125} \mathrm{I}\right] \mathrm{LDL}$. Diese Zunahme ist bedingt durch eine glucocorticoidspezifische Stimulation der LDL-Rezeptorsynthese um $40-50 \%$ und läßt sich durch eine vermehrte Inkorporation von $\left[{ }^{35}\right.$ S]Methionin in das durch Immunpräzipitation gewonnene Rezeptorprotein nachweisen. Die Syntheserate der zellulären Gesamtproteine und des lysosomalen Cathepsin D wird dagegen durch Dexamethason nicht signifikant beeinflußt.

Die glucocorticoid-abhängige Żunahme der LDL-Rezeptorsynthese ist begleitet von einer erhöhten Cholesterinsynthese aus $\left[2-{ }^{3} \mathrm{H}\right]$ Mevalonolacton bzw. $\left[1-{ }^{14} \mathrm{C}\right]$ Acetat. Die Glucocorticoid-induzierte Zunahme der Synthese des LDL -Rezeptors und des Cholesterins bleibt aus nach Vorinkubation der Zellen mit Dexamethason in Kombination mit 25-Hydroxycholesterin.

\section{Introduction}

Receptor specific binding and internalisation of homologous low density lipoproteins by human skin fibroblasts are known to initiate a suppression of

1) Abbreviations. LDE, low density lipoprotein; HMG-CoA, 3-hydroxy-3-methylglutaryl-CoA; SDS, sodium dodecyl sulphate.

2) Enzymes. Hydroxymethylglutaryl-CoA reductase (EC 1.1.1.88, mevalonate: NAD+ oxidoreductase). cellular cholesterol synthesis and an inhibition of LDL receptor synthesis (for review see 1.c. (1)). A correlation between the extent of cholesterol synthesis and the HMG-CoA reductase $\left.{ }^{1}\right),{ }^{2}$ ) activity has been observed in various systems in vivo and in vitro $(2-4)$ and is assumed to reflect the conversion of HMG-CoA into mevalonic acid as the rate-limiting step in the course of cholesterogenesis. However, various cell lines grown in the presence of glucocorticoids do not conform to this general rule. 
Thus, in HeLa cells the increased cholesterol synthesis from acetate after serum removal from the medium was partially suppressed by dexamethasone, but this suppression was not accompanied by an expected decrease in activity of HMG-CoA reductase (5). Also, in a variety of cell lines grown in the presence of dexamethasone the incorporation of acetate into cellular cholesterol was suppressed while HMG-CoA reductase activity was either elevated or remained unchanged $(6,7)$.

The glucocorticoid effect seems to depend on the sensitivity of the cell line and the glucocorticoid concentration. Thus, Brown \& Goldstein (4) have shown that growth of fibroblasts in the presence of cortisol had no effect on HMG-CoA reductase activity even at $10^{-5} \mathrm{~mol} / \mathrm{l}$ concentration while in HeLa and HTC cells (6) glucocorticoids were effective in the induction of HMG-CoA reductase at concentrations ranging from $10^{-6} \mathrm{~mol} / \mathrm{l}(6)$ to $10^{-8} \mathrm{~mol} / \mathrm{l}(5)$. Moreover, there was a demonștrated parallel between the magnitude of enzyme induction and glucocorticoid potency, so that the order of activity was dexamethasone > prednisolone $>$ cortisol (5).

The criteria used in previous studies on the influence of glucocorticoids on cholesterol metabolism were

(I) the incorporation of $\left[{ }^{14} \mathrm{C}\right]$ acetate or $\left[{ }^{3} \mathrm{H}\right] \mathrm{me}$ valonolactone into cholesterol (5-7),

(II) the activity of HMG-CoA reductase (4-7) and

(III) bindung and intracellular processing of LDL (8), but no information is available on the synthesis of the LDL receptor.

Therefore in the present studies we examined the biosynthesis of LDL receptor under the influence of dexamethasone and cortisol. The results are based on measurements of LDL receptor synthesis by immunoprecipitation and fluorography of LDL receptor after pulse labelling with $\left[{ }^{35} \mathrm{~S}\right]$ methionine, according to Tolleshaug et al. (9). Control experiments were performed to determine the synthesis of total cell protein, of cathepsin D (pulse labelled with $\left.{ }^{[35} \mathrm{S}\right] \mathrm{methionine}$ and immune precipitated), and of cellular cholesterol.

The presented data may be important not only in terms of the further understanding of the mechanism of action of glucocorticoids but could also contribute to a more rational use of steroid analogues as chemotherapeutical agents. We have therefore examined not only the physiological concentrations of glucocorticoids but also their therapeutical doses.

\section{Materials and Methods}

Materials

Steroids were purchased from Sigma, 25-hydroxycholesterol from Steraloids Inc. (Wilton, NH, USA), $\left[{ }^{35}\right.$ S]methionine from NEN, $\left[1-{ }^{14} \mathrm{C}\right]$ acetate, $D, L-\left[2-{ }^{3} \mathrm{H}\right]$ mevalonic acid lactone and ${ }^{125} \mathrm{I}$ (carrier free) from the Radiochemical Centre Amersham. All other chemicals used were from known spurces and of analytical grade. All steroids were dissolved in dimethyl sulphoxide and added to the culture medium to give a final dimethyl sulphoxide concentration which did not exceed $5 \mathrm{ml} / \mathrm{l}$ medium.

Methods

\section{Lipoprotein}

Human low density lipoproteins $(\mathrm{d}=1.02-1.055 \mathrm{~kg} / \mathrm{l})$ were isolated and labelled with ${ }^{125} \mathrm{I}$ as described previously (10) yielding specific activities of $8-12 \times 10^{4}$ counts/min $\cdot \mu \mathrm{g} \mathrm{LDL}$ protein. $95-97 \%$ of the radioactivity was precipitable with $100 \mathrm{~g} / \mathrm{l}$ trichloroacetic acid. Lipoprotein-deficient serum was prepared by ultracentrifugation at $\mathrm{d}=1.22 \mathrm{~kg} / \mathrm{l}$.

\section{Cells}

Normal human fibroblasts were grown from the skin explant of a normal infant and were used for incubation experiments between the third and eight passages. Incubation conditions are described in the corresponding figures and tables.

\section{Assays}

The binding, internalisation and degradation assays of [ $\left.{ }^{125} \mathrm{I}\right] \mathrm{LDL}$ were performed at $37^{\circ} \mathrm{C}$, using the method of Brown \& Goldstein (4). Bindung and uptake of ${ }^{125}$ I-labelled epidermal growth factor were determined according to Kita et al. (11). Protein was determined by the method of Kaltwasser et al. (12).

\section{Lipid analyses}

Lipids were extracted from the cell with chloroform: methanol $(2+1$ by volume $)$ and separated into individual lipid classes on silica $\mathrm{G}$ plates as described previously (13). Trace amounts of diglycerides were eliminated from the cholesterol fraction by digitonin precipitation.

\section{Antibodies against $L D L$ receptor}

The LDL receptor from bovine adrenal cortex membranes was isolated and purified according to Schneider et al. (14). Antibodies against the LDL receptor were produced in rabbits according to Kita et al. (11). Antibodies from goat directed against rabbit $\gamma$-globulins were a gift from Dr. B. Voss, Institute of Arteriosclerosis Research, Münster. Rabbit antibodies directed against human placental cathepsin D (15) were a gift from Dr. Gieselmann in the authors' institute.

\section{$L D L$ receptor synthesis}

LDL receptor was labelled by a 3 hour pulse of cultured cells with $5.6 \mathrm{GBq} / 1$ of $\left[{ }^{35} \mathrm{~S}\right]$ methionine in methionine-free medium. After extensive washings the cells were lysed, LDL receptor was precipitated from the cell lysate by specific antibodies and analysed by SDS electrophoresis as described (9). ${ }^{35} \mathrm{~S}$-Labelled cathepsin D was immune precipitated and analysed according to 1. c. (15).

The radioactivity in the receptor or cathepsin D bands was determined following digestion of the bands in a mixture of $\mathrm{H}_{2} \mathrm{O}_{2}$ and ammonia ( $99+1$ by volume) for 12 hours at $55^{\circ} \mathrm{C}$.

Incorporation of ${ }^{35}$ S]methionine into total cell proteins was - determined in an aliquot of cell lysates following trichloroacetic acid precipitation and extensive washing. 


\section{Radioactivity}

${ }^{125}$ I-Radioactivity was counted in a $\gamma$-counter (Berthold Modell 5300). ${ }^{35} \mathrm{~S}-,{ }^{3} \mathrm{H}$ - and ${ }^{14} \mathrm{C}$-radioactivity were determined by scintillation counting.

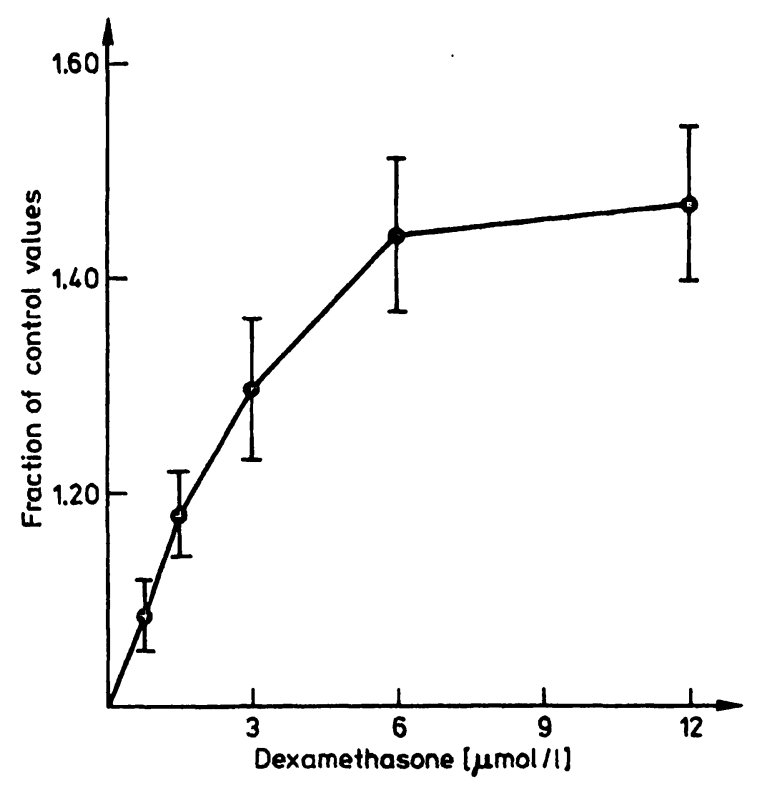

Fig. 1. Effect of dexamethasone on the binding of [125I]LDL to human skin fibroblasts. Cells were preincubated in lipoprotein-free medium for $48 \mathrm{~h}$ with the specified concentrations of dexamethasone prior to adding to the medium either $5 \mathrm{mg} / 1$ [125I]LDL or $5 \mathrm{mg} / 1$ [ $\left.{ }^{125} \mathrm{I}\right] \mathrm{LDL}+$ $300 \mathrm{mg} / 1 \mathrm{non}$-labelled LDL. High affinity binding was determined after $6 \mathrm{~h}$. Means and standard errors are calculated from 4 experiments made in duplicate. Figures of control experiments were set as 1.00 .

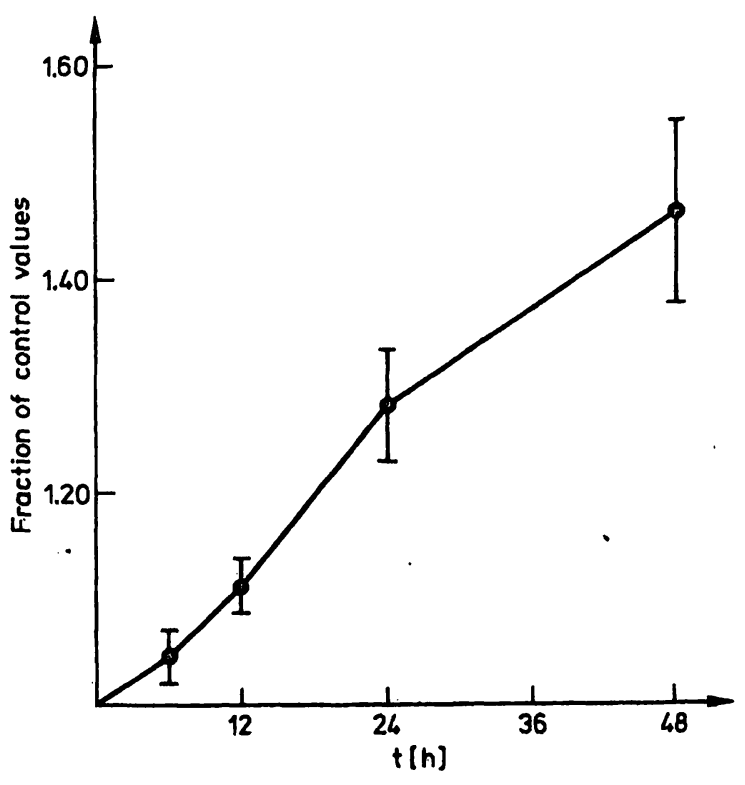

Fig. 2. Time-dependent increase of [125I]LDL binding to human skin fibroblasts after preincubation of the cells with 12 $\mu \mathrm{mol} / \mathrm{l}$ dexamethasone for the specified periods (control $=1.00$ ). Means and standard errors of 3 experiments. Incubation conditions as in figure 1.

\section{Results}

Preincubation of monolayers of human skin fibroblasts with dexamethasone causes a concentration-dependent increase (up to $50 \%$ ) of receptor-mediated binding (fig. 1), internalization and degradation (not shown) of LDL, compared with cell cultures preincubated without glucocorticoids or in the presence of oestradiol-17 $\beta$ (tab. 1). The effect on LDL binding is detectable after a short lag phase and reaches maximal values after preincubation of the cells in the presence of effective steroids for 48 hours (tab. 1, fig. 2).

The glucocorticoid-induced increase of LDL receptor activity was correlated with a stimulation of LDL receptor synthesis as indicated by a higher rate of incorporation of $\left[{ }^{35} S\right]$ methionine into receptor protein (tab. 2). SDS gel electrophoresis of the immune precipitate according to l.c. (8) yielded the mature LDL receptor and its precursor form as single bands with apparent molecular weights of about 160000 and 120000 respectively. The specificity of the antibody was ascertained by the observation that addition of $5 \mathrm{mg} / \mathrm{l}$ medium of immunoglobulin entirely prevented LDL from binding to the cell surface receptor. The increased labelling of the LDL receptor after preincubation of the cells in the presence of 6 and 12 $\mu \mathrm{mol} / \mathrm{l}$ dexamethasone as shown in figure $3 \mathrm{a}$ (left

Tab. 1. Effect of steroid hormones on metabolism of [ $\left.{ }^{125} \mathrm{I}\right] \mathrm{LDL}$ in human skin fibroblasts. Cells were preincubated for 48 hours with $12 \mu \mathrm{mol} / 1$ concentration of effectors in lipoprotein-deficient medium prior to adding $5 \mathrm{mg} / \mathrm{l}$ of [125I]LDL in the presence or absence of $300 \mathrm{mg} / \mathrm{l}$ of nonlabelled LDL apoprotein. After 6 hours cells were extensively washed, then trypsinised. High affinity binding, internalisation and degradation were calculated by subtracting the radioactivity bound, internalized and degraded in the presence from that obtained in the absence of nonlabelled LDL. Data are means \pm standard deviation of 5 experiments.

\begin{tabular}{|c|c|c|c|}
\hline \multirow{3}{*}{$\begin{array}{l}\text { Pre- } \\
\text { incubation } \\
\text { with }\end{array}$} & \multicolumn{3}{|c|}{$\left.{ }^{125} \mathrm{I}\right]$ LDL metabolism } \\
\hline & Binding & $\begin{array}{l}\text { Inter- } \\
\text { nalization }\end{array}$ & Degradation \\
\hline & \multicolumn{3}{|c|}{ (LDL apoprotein, $\mathrm{ng} / \mathrm{mg}$ cell protein) } \\
\hline $\begin{array}{l}\text { None } \\
\text { (control) }\end{array}$ & $126 \pm 15$ & $648 \pm 53$ & $2389 \pm 301$ \\
\hline $\begin{array}{l}\text { Dexa- } \\
\text { methasone }\end{array}$ & $180 \pm 24^{*}$ & $1063 \pm 146^{*}$ & $3889 \pm 519^{*}$ \\
\hline $\begin{array}{l}\text { Cortico- } \\
\text { sterone }\end{array}$ & $157 \pm 18^{*}$ & $926 \pm 89^{*}$ & $3043 \pm 317^{*}$ \\
\hline $\begin{array}{l}\text { Hydro- } \\
\text { cortisone }\end{array}$ & $162 \pm 29 * *$ & $894 \pm 91^{*}$ & $2987 \pm 246^{* *}$ \\
\hline $\begin{array}{l}\text { Oestra- } \\
\text { diol-17ß }\end{array}$ & $129 \pm 13$ & $627 \pm 32$ & $2334 \pm 172$ \\
\hline
\end{tabular}

* significance vs. control p $<0.01$

** significance vs. control $\mathrm{p}<0.05$ 
Tab. 2. Incorporation of $\left.{ }^{35}\right]$ methioninc into LDL-receptor protein, cathepsin $D$ and total cell protein of human skin fibroblasts as influenced by dexamethasone. Cells were preincubated for 48 hours in lipoprotein-deficient medium in the absence or presence of effectors and than pulsed for 3 hours with $5.6 \mathrm{GBq} / \mathrm{l}$ of $\left[{ }^{35} \mathrm{~S}\right]$ methionine (LDL-receptor) and for $30 \mathrm{~min}$ (cathepsin D) in methionine-free medium. Afterwards the cells were lysed and radioactivity in LDL receptor, cathepsin $\mathrm{D}$ and total protein was determined as described in Methods. Fraction of control values $(=1.00)$ in brackets. Data are means of duplicate values.

\begin{tabular}{lllll}
\hline $\begin{array}{l}\text { Preincubation } \\
\text { conditions }\end{array}$ & $\begin{array}{l}\text { Concentration } \\
(\mu \mathrm{mol} / \mathrm{l})\end{array}$ & $\begin{array}{l}\mathrm{LDL} \text { receptor } \\
(\text { counts/min } \cdot \mathrm{mg} \text { cell protein) }\end{array}$ & $\begin{array}{l}\text { Cathepsin D } \\
\text { (counts/min } \cdot \mathrm{mg} \text { cell protein) }\end{array}$ & $\begin{array}{l}\text { Cell protein } \\
\text { (counts/min } \cdot \mathrm{mg})\end{array}$ \\
\hline $\begin{array}{l}\text { Control } \\
\text { Dexamethasone }\end{array}$ & - & $8550(1.00)$ & $39040(1.00)$ & $181600000(1.00)$ \\
Dexamethasone & 6 & $11970(1.40)$ & $39480(1.01)$ & $176100000(0.97)$ \\
\hline
\end{tabular}

panel, track A and B) was confirmed by quantitative counting of the receptor bands (tab. 2). Cells preincubated in the presence of 6 and $12 \mu \mathrm{mol} / 1$ dexamethasone incorporated $40 \%$ and $48 \%$ more $\left[{ }^{35} S\right]$ methionine into the immune precipitated LDLreceptor protein than cells incubated in the absence of the effector. Preincubation of the cells with a

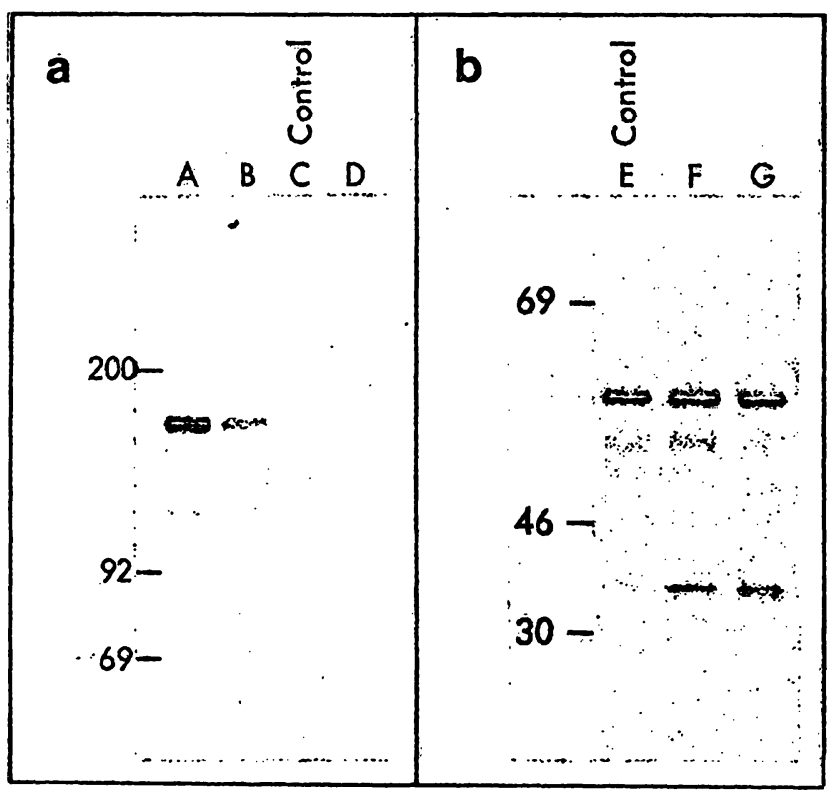

Fig. 3. Incorporation of $\left[{ }^{35} S\right]$ methionine into the LDL receptor (a) and cathepsin D (b) of human skin fibroblasts. After preincubation for $48 \mathrm{~h}$ in lipoprotein-free medium the cells were labelled for $3 \mathrm{~h}$ (LDL receptor) and $30 \mathrm{~min}$ (cathepsin D) with $\left.5.6 \mathrm{GBq} / 1{ }^{35} \mathrm{~S}\right]$ methionine, then washed and lysed. The LDL receptor and cathepsin D were immune precipitated from cell lysates, separated by SDS gel electrophoresis and visualized by fluorography. (a) Immune precipitates of LDL receptor from cells preincubated in the presence of $12 \mu \mathrm{mol} / \mathrm{l}(\mathrm{A})$, $6 \mu \mathrm{mol} / \mathrm{l}(\mathrm{B})$ or absence $(\mathrm{C}$, control) of dexamethasone and in the presence of a combination of $12 \mu \mathrm{mol} / \mathrm{l}$ dexamethasone, $20 \mathrm{mg} / \mathrm{l}$ cholesterol, and $1 \mathrm{mg} / 1$ of 25 hydroxycholesterol (D). (b) Immune precipitates of cathepsin $D$ from cells preincubated in the presence of $6 \mu \mathrm{mol} / \mathrm{l}(\mathrm{F})$ and $12 \mu \mathrm{mol} / \mathrm{l}$ dexamethasone (G). E, control. combination of dexamethasone and 25hydroxycholesterol (fig. 3a, left panel, track D) completely abolished the incorporation of $\left.{ }^{[35} \mathrm{S}\right]$ methionine into the LDL receptor protein.

In control experiments the rate of synthesis of lysosomal cathepsin $\mathrm{D}$ as influenced by dexamethasone was determined under strictly identical conditions. SDS gel electrophoresis of immune precipitated cathepsin D after pulse labelling with $\left[{ }^{35}\right.$ S]methionine results in the formation of a 53000 dalton precursor, a 47000 dalton intermediate and a 31000 dalton mature form. As shown in figure $3 \mathrm{~b}$ (right panel) and table 2, dexamethasone has no influence on the sum of $\left[{ }^{35} \mathrm{~S}\right]$ methionine incorporated into the different forms of cathepsin D.

Incorporation of $\left[{ }^{35}\right.$ S $]$ methionine into the total cell protein was not elevated under the influence of dexamethasone in relation to controls (tab. 2).

The glucocorticoid-enhanced LDL receptor activity and synthesis was found to be glucocorticoid-specific but not LDL receptor-specific. Thus, after preincubation of the cells with $12 \mu \mathrm{mol} / \mathrm{l}$ dexamethasone the receptor mediated binding and internalisation of $\left[{ }^{125} \mathrm{I}\right]$ epidermal growth factor is augmented from the control values ( $37 \pm 6 \mathrm{ng} / \mathrm{mg}$ cell protein) to 64 $\pm 7 \mathrm{ng} / \mathrm{mg}$ cell protein. The glucocorticoid-induced increase of LDL receptor synthesis and LDL receptor activity is abolished by preincubation of the cells with cycloheximide, native LDL (not shown) or with a combination of dexamethasone and 25-hydroxycholesterol (fig. 3, Track $\mathrm{C}$ and tab. 2).

The incorporation of $\left[2-{ }^{3} \mathrm{H}\right]$ mevalonolactone and $\left[1-{ }^{14} \mathrm{C}\right]$ acetate into cholesterol are increased by dexamethasone to the same extent as the LDL receptor activity and synthesis, these effects being prevented likewise by a preincubation of the cells with dexamethasone in combination with 25-hydroxycholesterol (tab. 3). .; 
Tab. 3. Incorporation of $\left[1-{ }^{14} \mathrm{C}\right]$ acetate and $\left[2-{ }^{3} \mathrm{H}\right]$ mevalonolactone into cellular cholesterol of human skin fibroblasts. Cells were preincubated for $48 \mathrm{~h}$ in lipoprotein-deficient medium in the presence or absence of the specified effectors and then radiolabelled for a further $6 \mathrm{~h}$ with $3.7 \mathrm{GBq} / \mathrm{l}$ of either $\left[1-{ }^{14} \mathrm{C}\right] \mathrm{acetate}$ or $\left[2-{ }^{3} \mathrm{H}\right]$ mevalonolactone. The total lipids extracted from the cells were fractionated on silica-G plates-and the cholesterol analysed for radioactivity. Data are means \pm standard deviation of 4 experiments.

\begin{tabular}{|c|c|c|c|}
\hline Preincubation with & $\begin{array}{l}\text { Concentration } \\
(\mu \mathrm{mol} / \mathrm{l})\end{array}$ & $\begin{array}{l}\text { Cholesterol synthesis } \\
{\left[1-{ }^{14} \mathrm{C}\right] \text { Acetate }} \\
\text { (counts/min } \cdot \mathrm{mg} \text { cell protein) }\end{array}$ & $\begin{array}{l}{\left[{ }^{3} \mathrm{H}\right] \mathrm{Meval} \text { onolactone }} \\
\text { (counts/min } \cdot \mathrm{mg} \text { cell protein) }\end{array}$ \\
\hline None & - & $800000 \pm 10000$ & $96000 \pm 11000$ \\
\hline Dexamethasone & 12 & $1200000 \pm 170000$ & $138000 \pm 14000$ \\
\hline $\begin{array}{l}\text { Dexamethasone } \\
+25 \text {-Hydroxycholesterol }\end{array}$ & $12+2.5$ & $<50000$ & n. d. \\
\hline
\end{tabular}

n. d., not determined

\section{Discussion}

The present studies provide evidence that treatment of cultured human fibroblasts with synthetic or natural glucocorticoids initiates a stimulation of LDL receptor synthesis. This was indicated by a higher rate of ${ }^{35}$ S $]$ methionine incorporation into the LDL receptor protein, which was measured after immunoprecipitation with specific antibodies. The enhanced rate of receptor synthesis is accompanied by an increased binding and internalization of [ $\left.\left.{ }^{125}\right]\right] \mathrm{LDL}$, providing evidence that an increased receptor synthesis increases the number of cell membrane bound functional LDL receptors. As a concomitant effect an increase in the incorporation of $\left[2-{ }^{3} \mathrm{H}\right]$ mevalonolactone and $\left[1-{ }^{14} \mathrm{C}\right]$ acetate into cholesterol was observed.

In our fibroblast culture systems glucocorticoids were ineffective at physiological concentration $\left(10^{-7} \mathrm{~mol} / \mathrm{l}\right)$. This confirms earlier findings that human skin fibroblasts seem to be less sensitive towards glucocorticoids than other cell lines. Whereas in HeLa $(6,7)$ and HTC $(6)$ cells pretreated with $10^{-6}$ mol/l dexamethasone the HMG-CoA reductase catalytic activity increased to $175-200 \%$ of the control values, in fibroblasts (2) the enzyme activity was not significantly affected, evèn at $10^{-5} \mathrm{~mol} / \mathrm{l}$ dexamethasone. Also Henze et al. (16) observed an unchanged binding of LDL by cultured human skin fibroblasts pretreated with $4.1 \times 10^{-8} \mathrm{~mol} / \mathrm{l}$ hydrocortisone. In the present experiment the glucocorticoid dose required for stimulation of LDL receptor synthesis $\left(5-10 \times 10^{-6} \mathrm{~mol} / \mathrm{l}\right)$ corresponds to the serum glucocorticoid level after application of therapeutic doses of glucocorticoids.

The mechanism by which dexamethasone stimulates LDL receptor synthesis is not yet clear. In HeLa cells high affinity binding of LDL was not affected by $10^{-6} \mathrm{~mol} / 1$ dexamethasone but processing of LDL after its internalisation was altered so that the cellassociated LDL was reduced by dexamethasone to $20-60 \%$ of the control value (8). Also, Henze et al. (16) observed an unchanged binding but a decreased internalization and degradation of LDL by cultured human skin fibroblasts pretreated with physiological concentrations of hydrocortisone.

An inverse effect is observed in cultured fibroblasts at $5-10 \times 10^{-6} \mathrm{~mol} / \mathrm{l}$ dexamethasone. The data in table 1 show an enhanced binding and internalisation of $\left.{ }^{125} \mathrm{I}\right] \mathrm{LDL}$ as a result of an increased LDL receptor synthesis (fig. 3), but it appears doubtful whether this effect reflects a physiological action of glucocorticoids. The fact that the dexamethasoneinduced increase of LDL receptor synthesis could be suppressed when the cells were incubated with a combination of dexamethasone and 25-hydroxycholesterol suggests that dexamethasone in higher concentrations prevents the intracellular formation of oxygenated cholesterol derivatives which are known to be powerful inhibitors of cholesterol biosynthesis in various types of cells in culture and in vivo (17). Such oxygenated sterols, for example 24,25 oxidolanosterol (18) are generated from squalene 2,3:22:23-dioxide, which can be metabolized into compounds more polar than cholesterol. Squalene 2,3:22:23-dixoide is not a normal intermediate of cholesterol biosynthesis, but is formed from squalene 2,3-epoxide (an obligatory precursor of cholesterol) when the enzyme squalene 2,3-epoxide cyclase is partially inhibited (19). A complete inhibition of squalene 2,3 epoxide cyclase, however, would prevent the formation of oxygenated sterols and hence lessen the inhibition of HMG-CoA reductase, with the result that cholesterol and LDL receptor synthesis are stimulated.

The glucocorticoid-induced increase of LDL receptor synthesis was shown to exhibit relative specificity. 
Thus, on the one hand the rate of synthesis of a lysosomal marker enzyme, cathepsin D, was not influenced and the synthesis of total cell protein was not elevated by dexamethasone. On the other hand not only the endocytosis uptake of LDL but also the receptor-mediated endocytosis of the epidermal growth factor was enhanced by dexamethasone. This is in accordance with findings of Sadig et al. (15), who observed a betamethasone-induced increase of foetal pulmonary epidermal growth factor. From these results it is concluded that glucocorticoids in the concentrations used effect a selective augmentation in the synthesis of glucocorticoid dependent proteins, but do not exert a general stimulating effect on protein biosynthesis. The elevated incorporation of $\left[2-{ }^{3} \mathrm{H}\right]$ mevalonolactone and $\left[{ }^{14} \mathrm{C}\right]$ acetate into cholesterol suggests that pace maker enzymes of cholesterol synthesis are regulated by glucocorticoids.

\section{References}

1. Goldstein, J. L. \& Brown, M. S. (1977) Ann. Rev. Biochem. 46, 897-930.

2. Siperstein, M. D. \& Fagan, V. M. (1966) J. Biol. Chem. 241, 602-609.

3. Rodwell, V. M., McNamara, D. J. \& Shapiro, D. J. (1973) Adv. Enzymol. 38, 373-411.

4. Brown, M. S. \& Goldstein, J. L. (1974) J. Biol. Chem. 249, 7306-7314.

5. Cavenee, W. K. \& Melnykovych, G. M. (1977) J. Biol. Chem. 252, 3272-3276.

6. Johnston, D., Cavenee, W. K., Ramachandran, K. \& Melnykovych, G. (1979) Biochim. Biophys. Actạ 5.72, $188-192$.

7. Cavenee, W. K., Johnston, D. \& Melnykovych, G. (1978) Proc. Natl. Acad. Sci. USA 75, 2103-2107.

8. Johnston, D., Robson, J. M. \& Melnykovych, G. (1983) Endocrinology 113, 907-914.

9. Tolleshaug, H., Goldstein, J. L., Schneider, W. J. \& Brown, M. S. (1982) Cell 30, 715-724.

10. Filipovic, I. \& Buddecke, E. (1979) Biochem. Biophys. Res. Commun. 88, 485-490.

11. Kita, T., Beisiegel, U., Goldstein, J. L., Schneider, W. J. \& Brown, M. S. (1981) J. Biol. Chem. 256, 4701-4703.

12. Kaltwasser, F., Wolters, G. \& Pieper, J. (1965) Clin. Chim. Acta 15, 347-351.

13. Filipovic, I. \& Buddecke, E. (1981) Biochim. Biophys. Acta $647,112-118$

14. Schneider, W. J., Beisiegel, U., Goldstein, J. L. \& Brown, M. S. (1982) J. Biol. Chem. 257, 2664-2673.

15. Gieselmann, V., Pohlmann, R., Hasilik, A. \& von Figura, K. (1983) J. Cell Biol. 97, 1-5.

16. Henze, K., Chait, A., Albert, J. J. \& Biermann, E. L. (1983) Eur. J. Clin. Invest. 13, 171 -177 .

17. Gibbons, G. F., Pullinger, C. R., Chen, H. W., Cavenee, W. K. \& Kandutsch, A. A. (1980) J. Biol. Chem. 255, $395-400$.

18. Nelson, J. A., Steckbeck, S. R. \& Spencer, T. A. (1981) J. Biol. Chem. 256, 1067-1068. J. Am. Chem. Soc. 103, 6974-6975.

19. Panini, S. R., Sexton, R. C. \& Rudney, H. (1984) J. Biol. Chem. 259, 7767-7771.

20. Sadig, K., Chait, A., Albert, J. J: \& Biermann, E. L. (1983) Biochem. Biophyś. Rès. Commun. 119, 408-414.

Prof. Dr. Ivan Filipovic

Prof. Dr. Eckhart Buddecke

Institut für Physiologische Chemie

der Universität

Waldeyerstraße 15

D-4400 Münster 